\title{
Komposisi dan Kelimpahan Gastropoda pada Ekosistem Mangrove di Desa Tireman, Kabupaten Rembang, Jawa Tengah
}

\author{
Yuli Laraswati*, Nirwani Soenardjo, Wilis Ari Setyati \\ Departemen IImu Kelautan, Fakultas Perikanan dan IImu Kelautan, Universitas Diponegoro \\ Jl. Prof H.Soedharto S H, Tembalang, Semarang, Jawa Tengah 50275 Indonesia \\ ${ }^{*}$ Corresponding author, e-mail : yulilaraswati11@gmail.com
}

\begin{abstract}
ABSTRAK : Ekosistem mangrove memiliki manfaat sebagai tempat mencari makan serta habitat bagi organisme, mislanya gastropoda. Gastropoda di ekosistem mangrove berperan dalam proses dekomposisi yaitu dengan mencacah daun menjadi lebih kecil, yang kemudian dilanjutkan oleh mikroorganisme. Kepadatan gastropoda dipengaruhi oleh kegiatan yang terdapat pada ekosistem dan dapat memberikan efek pada kelangsungan hidup gastropoda. Tujuan penelitian adalah untuk mengetahui struktur komunitas gastropoda pada ekosistem mangrove Desa Tireman Kecamatan Rembang, Jawa Tengah. Metode penentuan lokasi sampling menggunakan metode purposive sampling pada 3 lokasi dengan kerapatan mangrove yang berbeda. Pengambilan sampel gastropoda dilakukan dalam transek 5 x 5m dan sampel yang didapat kemudian disortir, diawetkan dan diidentifikasi. Hasil penelitian ditemukan 9 spesies gastropoda termasuk kedalam 3 famili yaitu Casidula nucleus, C. aurisfelis (Ellobiidae), Littoraria scabra, L. carinifera, L. Melanostama (Littorinidae), Cerithidea quadrata, C. cingulata, C. alata, Telescopium telescopium (Potamididae). Spesies yang paling sering ditemukan adalah Cassidula aurisfelis dan Cassidula nucleus. Nilai rata-rata kelimpahan berkisar antara $6,28-5,72 \mathrm{ind} / \mathrm{m}^{2}$. Nilai indeks keanekaragaman termasuk ke dalam kategori rendah hingga sedang. Nilai rata-rata indeks keseragaman termasuk kedalam kategori rendah (0.15-0.27). Nilai rata-rata indeks dominansi menunjukkan tidak adanya dominansi dari spesies tertentu. Pola sebaran menunjukkan pola sebaran mengelompok dan acak. Nilai kesamaan komunitas gastropoda tergolong dalam kategori tinggi. Frekuensi kehadiran gastropoda kategori jarang hingga sangat sering.
\end{abstract}

Kata Kunci : Gastropoda; Komposisi; Desa Tireman

\section{Composition and Abundance of Gastropods In Mangrove Ecosystems inTireman Villages, Rembang Regency, Central Java}

ABSTRACT: The mangrove ecosystem has benefits as a place to eat and habitat for the organism, the gastropod's missile. Gastropods in the mangrove ecosystem play a role in the decomposition process, with the smaller leaves, which are then followed by microorganisms. The density of gastropods is influenced by activities found in ecosystems and can provide an effect on the viability of gastropods. The purpose of research is to know the structure of the gastropods community in the mangrove ecosystem of Tireman Village Rembang District, Central Java. Sampling method of determining location using purposive sampling method in 3 locations with different mangrove density. The gastropod sampling is done in the $5 \times 5 \mathrm{~m}$ transect and the samples obtained are then sorted, preserved and identified. The results of the study found 9 species of gastropods included in the three families, namely Casidula nucleus, C. Aurisfelis (Ellobiidae), Littoraria scabra, L. Carinifera, L. Melanostama (Littorinidae), Cerithidea quadrata, C. cingulata, C. alata, Telescopium telescopium (Potamididae). The most commonly found species are the Cassidula aurisfelis and the Cassidula nucleus. The average value of abundance ranges between $6.28-15.72 \mathrm{ind} / \mathrm{m}^{2}$. The value of diversity index belongs to low to moderate category. The average value of uniformity index is included in low category (0.15-0.27). The average value of the Dominancy index indicates the absence of dominance of a particular species. The spread pattern shows both group and random distribution patterns. The value of gastropods community similarity belongs to high category. The frequency of presence of gastropods is rare until very frequent.

Keywords: Gastropods; Composition; Tireman villages 


\section{PENDAHULUAN}

Ekosistem mangrove merupakan kawasan hutan yang hidup di sepanjang garis pantai dan dipengaruhi oleh pasang surut air laut. Menurut Printrakoon dan Tëmkin (2008) ekosistem mangrove merupakan salah satu ekosistem alamiah yang unik dan mempunyai nilai ekologis dan ekonomis yang tinggi. Fungsi ekosistem mangrove antara lain sebagai pelindung pantai dari angin, arus dan ombak dari laut, habitat (tempat tinggal), tempat mencari makan (feeding ground), dan tempat pemijahan (spawning graund) bagi biota perairan. Salah satu biota yang hidup di ekosistem mangrove yaitu gastropoda.

Gastropoda merupakan kelompok hewan bertubuh lunak, umumnya memiliki cangkang dan hidup menempel pada akar dan batang mangrove serta pada permukaan sedimen. Biota ini mempunyai peran penting dalam fungsi ekologis pada ekosistem mangrove yaitu sebagai fauna yang berperan dalam rantai makanan pada ekosistem mangrove. Gastropoda berperan dalam poses dekomposisi serasah, dengan kata lain gastropoda berkedudukan sebagai dekomposer awal. Menurut Nurrudin et al. (2015), gastropoda pada ekosistem mangrove merupakan pemakan detritus yang berperan dalam merobek dan memperkecil serasah yang jatuh untuk mempercepat proses dekomposisi yang dilakukan mikroorganisme. Gastropoda sangat mudah ditemukan di ekosistem mangrove karena ekosistem tersebut merupakan habitat, mencari makan, dan tempat pemijahan bagi gastropoda. Tekanan akibat dari adanya penebangan mangrove, pembuangan sampah akan menyebabkan kerusakan pada ekosistem mangrove. Rusaknya ekosistem mangrove maka akan mempengaruhi kehidupan semua biota yang hidup didalamnya, termasuk gastropoda.

Pertengahan tahun 1964, pesisir sepanjang Kabupaten Rembang, termasuk Desa Tireman, daratan pinggir pantai yang umumnya berupa kawasan mangrove dan tambak mengalami kerusakan akibat abrasi (Anggraini, 2016). Tahun 2003 luasan mangrove Desa Tireman 3.830 ha, tahun 2013 mengalami pertambahan luasan yaitu seluas 13.321 ha, namun pada tahun 2018 luasan mangrove Desa Tireman mengalami penurunan menjadi 10.968 ha (Harsioko, 2018). Menurut Annas et al., (2013) permasalahan yang menyebabkan kerusakan mangrove dikarenakan kegiatan perluasan pertambakan udang dan garam, penebangan pepohonan untuk berbagai kebutuhan, abrasi dan sampah. Hal ini dapat menyebabkan semakin menurunnya kualitas ekosistem mangrove seperti keberadaan biota gastropoda berkurang jumlahnya. Kegiatan manusia pada kawasan ekosistem mangrove diduga akan memberikan dampak negatif bagi kelestarian habitat alamiah gastropoda karena pada kondisi berbeda gastropoda peka terhadap perubahan lingkungan sehingga akan berpengaruh terhadap keanekaragaman jenis dan kepadatanya. Tujuan penelitian ini adalah untuk mengetahui komposisi dan kelimpahan gastropoda di ekosistem mangrove Desa Tireman, Rembang, Jawa Tengah.

\section{MATERI DAN METODE}

Materi dalam penelitian yaitu seluruh gastropoda dan sedimen. Pengambilang sedimen bertujuan untuk analisis kandungan bahan organik dan ukuran butir. Parameter lingkungan yang di ukur meliputi salinitas, $\mathrm{pH}$, suhu dan DO yang dilakukan secara langsung (in situ). Analisis sedimen dilakukan di Laboratorium IImu Nutrisi dan Pakan Fakultas Peternakan dan Pertanian dan Laboratorium Mekanika Tanah Fakultas Teknik, Universitas Diponegoro. Metode yang digunakan dalam penelitian ini adalah metode deskriptif. Penentuan lokasi penelitian dengan metode Purpossive sampling. Pemilihan lokasi penelitian ini berdasarkan kerapatan mangrove yang berbeda sehingga dapat diketahui komposisi dan kelimpahan gastropoda pada lokasi dengan kondisi lingkungan yang berbeda. Lokasi penelitian di Desa Tireman. Pengambilan sampel dengan metode Sasekumar (1974), yaitu metode kualitatif menggunakan plot $5 \mathrm{~m} \times 5 \mathrm{~m}$ dengan hand picking. Sampel gastropoda dimasukkan ke dalam botol sampel berisi larutan Formalin $4 \%$ untuk pengawetan. Dilakukan identifikasi sampel gastropoda dengan mengacu pada buku identifikasi FAO Volume 1 (1998).

Kelimpahan suatu organisme dalam suatu perairan dapat dinyatakan sebagai jumlah individu persatuan luas (Barus, 2001). Satuan untuk kelimpahan pada penelitian ini adalah ind $/ \mathrm{m}^{2}$. Indeks keanekaragaman jenis merupakan karakteristik dari suatu komunitas yang menggambarkan 
tingkat keanekaragaman yang terdapat dalam komunitas tersebut. Indeks keanekaragaman jenis menggunakan rumus Shanon-Wieaner, 1963. Indeks keseragaman menunjukkan pola sebaran biota. Bertujuan mengetahui seberapa besar kesamaan penyebaran jumlah individu tiap jenis gastropoda digunakan indeks keseragaman, yaitu dengan cara membandingkan indeks keanekaragaman dengan nilai maksimumnya. Indeks dominansi adalah derajat pada dominansi dari satu, beberapa atau banyak jenis. Untuk mengetahui adanya dominasi jenis tertentu di perairan dapat digunakan indeks dominasi Simpson. Pola sebaran jenis merupakan metode yang digunakan untuk mengetahui sebaran suatu kelompok mahluk hidup di suatu tempat. Perhitungan pola sebaran jenis menurut Krebs (1989).

\section{HASIL DAN PEMBAHASAN}

Spesies gastropoda yang ditemukan pada penelitian ini disajikan pada Tabel 1 , dari tabel tersebut dapat dilihat bahwa pada penelitian ini ditemukan 9 spesies dari 3 famili yaitu Casidula nucleus (Ellobiidae), Cassidula aurisfelis (Ellobiidae), Cerithidea quadrata (Potamididae), Cerithidea cingulata (Potamididae), Cerithidae alata (Potamididae), Telescopium telescopium (Potamididae), Littoraria scabra (Littorinidae), Littoraria carinifera (Littorinidae), Littoraria melanostama (Littorinidae).

Hasil penelitian menunjukkan bahwa di area mangrove di Desa Tireman, Rembang ditemukan 3 famili gastropoda yaitu Littorinidae, Ellobidae, dan Potamididae. Spesies yang ditemukan berjumlah 9 spesies gastropoda yaitu Cassidula nucleus, Cassidula aurisfelis, Littorina melanostoma, Telescopium telescopium, Littoraria scabra, Littoraria carinifera, Cerithidea alata, Cerithidea cingulata, Cerithidea quadrata. Hal serupa ditemukan oleh Sulistiowati (2017) di Kawasan Mangrove Desa Pasar Banggi, Rembang menemukan 5 famili yaitu Ellobiidae, Littorinidae, Neritidae, Potamididae dan Assimineidae. Dahuri et al. (2000) menyatakan bahwa pembukaan tambak untuk budidaya perairan merupakan salah satu kegiatan yang memberikan kontribusi paling besar dalam perusakan ekosistem mangrove khususnya di wilayah Pantai Utara Jawa.

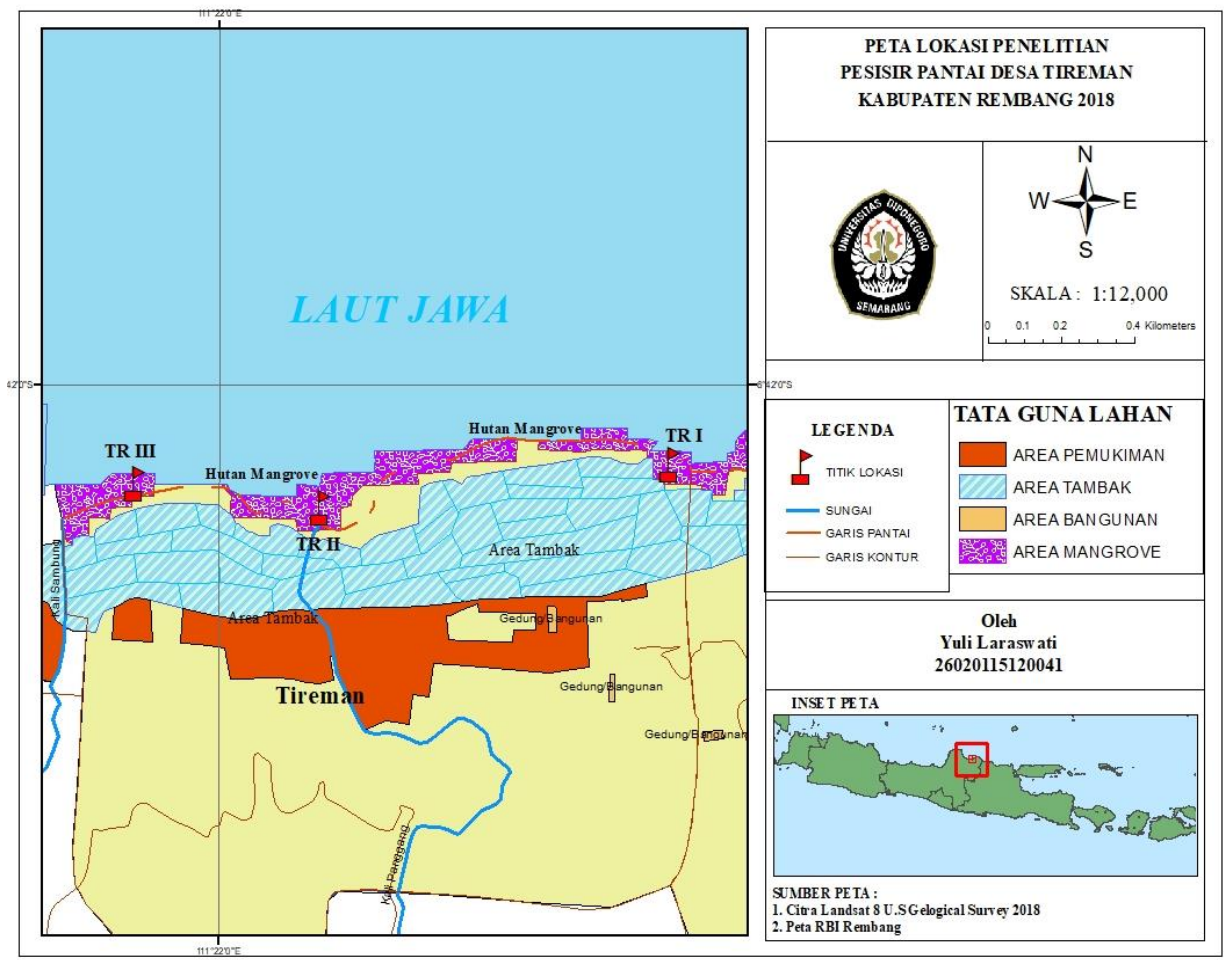

Gambar 1. Peta Lokasi Pengambilan Sampel di Ekosistem Mangrove Desa Tireman Kabupaten Rembang, Jawa Tengah. 
Secara umum, kelimpahan gastropoda antar stasiun menunjukkan nilai yang bervariasi. Kelimpahan rata-rata tertinggi terdapat pada stasiun TR I yaitu sebesar $15.72 \mathrm{Ind} / \mathrm{m}^{2}$. Selanjutnya diikuti oleh TR III dengan kelimpahan rata-rata sebesar $8.48 \mathrm{Ind} / \mathrm{m}^{2}$ dan nilai kelimpahan terendah pada TR II sebesar $6.28 \mathrm{Ind} / \mathrm{m}^{2}$ (Gambar 2).

Nilai rata-rata kelimpahan total gastropoda di lokasi penelitian adalah $91.44 \mathrm{ind} / \mathrm{m}^{2}$. Jumlah ini jauh lebih rendah dibandingkan dengan kelimpahan yang ditemukan dengan kelimpahan yang ditemukan oleh Sulistiowati (2017) dengan nilai rata-rata total sebesar $451 \mathrm{ind} / 25 \mathrm{~m}^{2}$ di Pasar Banggi, Rembang. Nilai rata-rata kelimpaan yang bervariasi antara penelitian satu dengan yang lain, diduga karena kondisi lingkungan yang berbeda dan jumlah stasiun penelitian yang berbeda sehingga mempengaruhi nilai kelimpahan gastropoda. Menurut Mujiono (2011) Perbedaan kerapatan mangrove dan bahan organik pada setiap stasiun di duga mempengaruhi kelimpahan, semakin rapat mangrove maka bahan organik yang dihasilkan akan semakin tinggi.

Tabel 1. Komposisi Spesies Gastropoda yang ditemukan pada Setiap Stasiun Penelitian di Desa Tireman, Rembang

\begin{tabular}{|c|c|c|c|c|c|c|c|c|c|c|}
\hline \multirow{2}{*}{ Famili } & \multirow{2}{*}{ Spesies } & \multicolumn{3}{|c|}{ TR I } & \multicolumn{3}{|c|}{ TR II } & \multicolumn{3}{|c|}{ TR III } \\
\hline & & $\mathrm{P} 1$ & $\mathrm{P} 2$ & P3 & $\mathrm{P} 1$ & $\mathrm{P} 2$ & P3 & $\mathrm{P} 1$ & $\mathrm{P} 2$ & P3 \\
\hline Ellobiidae & Casidula nucleus & + & + & + & + & + & + & + & + & + \\
\hline Ellobiidae & Cassidula aurisfelis & + & + & + & + & + & + & + & + & + \\
\hline Potamididae & Cerithidea quadrata & + & + & + & + & - & + & + & - & - \\
\hline Potamididae & Cerithidea cingulata & - & - & + & + & - & - & - & + & - \\
\hline Potamididae & Telescopium telescopium & - & + & - & - & - & - & + & - & - \\
\hline Potamididae & Cerithidea alata & - & - & - & - & + & - & + & - & + \\
\hline Littorinidae & Littoraria melanostama & + & + & + & - & - & + & + & - & + \\
\hline Littorinidae & Littoraria carinifera & + & + & - & - & - & - & - & - & - \\
\hline Littorinidae & Littoraria scabra & + & + & + & - & + & - & - & + & + \\
\hline & Jumlah & 6 & 7 & 6 & 4 & 4 & 4 & 6 & 4 & 5 \\
\hline & Rata-rata & & 6,3 & & & 4 & & & 5 & \\
\hline
\end{tabular}

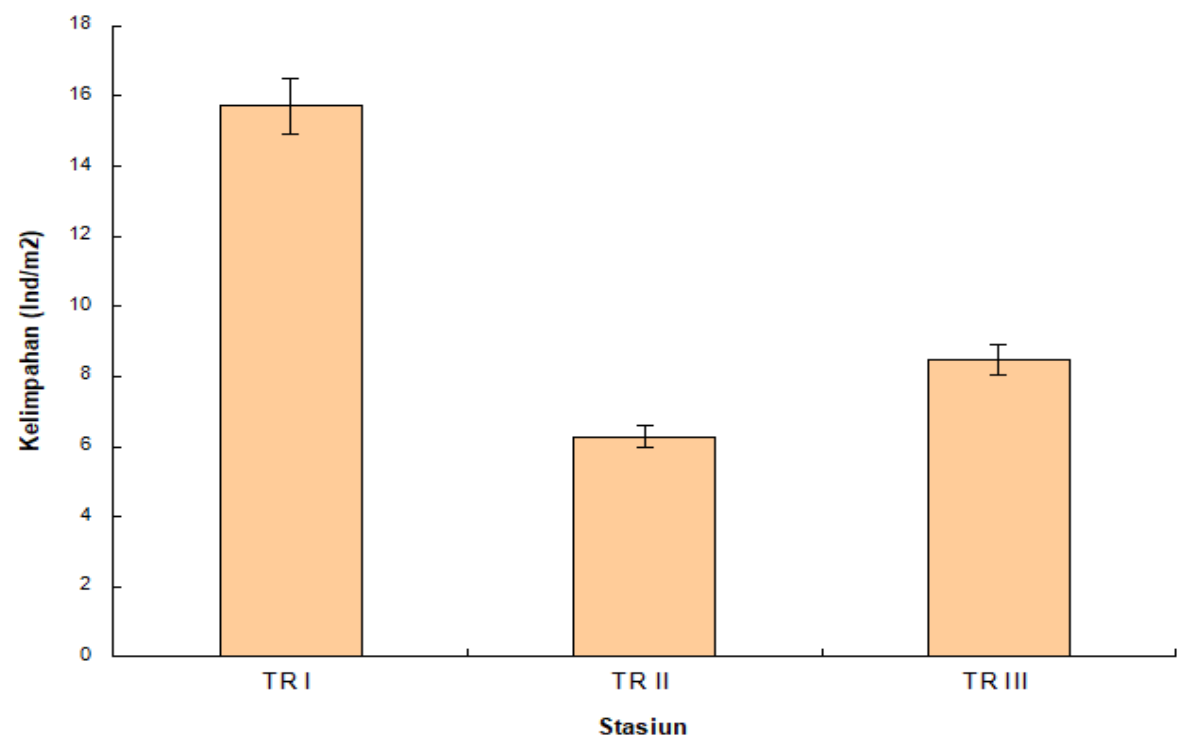

Gambar 2. Kelimpahan Rata-rata $\left(\mathrm{Ind} / \mathrm{m}^{2}\right)$ Gastropoda di Ekosistem Mangrove Desa Tireman, Rembang 
Kondisi substrat pada lokasi penelitian menunjukkan perbedaan yaitu lempung, lanau dan pasir. Menurut Syamsurial (2011) bahwa gastropoda cenderung memilih substrat lanau berpasir dikarenakan pasir mudah untuk bergeser dan bergerak ke tempat lain, sedangkan lanau cenderung memiliki kadar oksigen sedikit, oleh sebab itu organisme yang hidup didalamnya akan beradaptasi. Menurut Imam et al. (2014) kondisi substrat berpengaruh terhadap perkembangan komunitas gastropoda karena substrat yang terdiri dari lumpur dan berpasir sedikit liat merupakan substrat yang sesuai untuk gastropoda. Menurut Fadli et al. (2012) kelimpahan individu setiap spesies berhubungan dengan pola adaptasi masing-masing spesies, seperti tersedianya berbagai tipe substrat, makanan dan kondisi lingkungan. Nilai kelimpahan rata - rata gastropoda di lokasi penelitian tertinggi pada stasiun TR I $\left(15.72 \mathrm{ind} / \mathrm{m}^{2}\right)$, kemudian diikuti oleh stasiun TR II $(6.28$ ind $\left./ \mathrm{m}^{2}\right)$ dan TR III (8.48 ind $/ \mathrm{m}^{2}$ ). Nilai kelimpahan rata-rata di stasiun TR I lebih tinggi dibandingkan dengan stasiun lain karena nilai kerapatan mangrove di stasiun TR I lebih tinggi dibanding yang lain yaitu sebesar 2867 ind/ha,kerapatan mangrove TR II sebesar 2100 ind/ha dan TR III Nilai Kerapatan mangrove sebesar 1967 ind/ha. Keadaan tersebut mengakibatkan guguran daun mangrove dan serasah cukup banyak yang mengakibatkan sedimen yang ada di daerah tersebut memiliki kandungan bahan organik yang tinggi. Hogart (2007) menyatakan bahwa pada daerah mangrove dengan kerapatan tinggi membawa dampak kandungan bahan organik yang cukup tinggi. Tingginya kandungan bahan organik yang di peroleh pada TR I sebesar $37,17 \%$, TR II sebesar $24,17 \%$ dan TR III sebesar $12,83 \%$ sehingga melimpahnya bahan makanan untuk gastropoda yang berasal dari serasah mangrove. Kandungan bahan organik yang cukup banyak maka akan memberikan kesempatan kepada gastropoda untuk hidup dan tumbuh berkembang. Menurut Tambayong et al. (2017) yang menyatakan bahwa pada suatu perairan yang berbahan organik cukup tinggi maka akan menjadi habitat dan tempat pembesaran berbagai jenis biota bentik yang bervariasi termasuk didalamnya gastropoda.

Menurut Nyabakken (1992), bahwa indeks keanekaragaman suatu komunitas mempunyai nilai tinggi menunjukkan bahwa ekosistem di daerah tersebut memiliki lingkungan yang seimbang, apabila nilai keanekaragaman rendah menunjukkan ekosistem perairan tersebut dalam keadaan tidak stabil dan kurang mendukung kehidupan biota. Perbandingan hasil nilai indeks keanekaragaman, keseragaman dan dominansi secara keseluruhan disajikan pada Gambar 3. Nilai indeks keanekaragaman tertinggi yaitu pada stasiun TR III kemudian dilanjutkan stasiun TR I dan terendah pada TR II. Indeks keseragaman tertinggi pada stasiun TR III kemudian dilanjutkan TR I dan TR II. Nilai indeks dominansi tertinggi pada stasiun TR II kemudian dilanjutkan TR I dan terendah pada stasiun TR III (Gambar 3).

Nilai Indeks Keanekaragaman kategori sedang di TR I (1.04), kemudian diikuti TR III sebesar 1.22, dan TR II sebesar 0.81 termasuk dalam kategori rendah. Nilai rata - rata indeks keanekaragaman yang didapat diduga karena jumlah spesies yang didapatkan setiap plot tidak berbeda jauh. Menurut Nurfitriani (2017), tinggi rendahnya nilai indeks keanekaragaman disebabkan oleh bebrapa faktor diantaranya jumlah jenis dan spesies yang didapat. Jika didalam suatu komunitas memiliki nilai Keanekaragaman berkategori sedang maka diduga akan terjadi suatu interaksi antar spesies yang menimbulkan kompetisi, produktivitas cukup, kondisi ekosistem yang cukup seimbang dan tekanan ekologis yang sedang. Nilai indeks keanekaragaman pada semua stasiun tergolong sedang, menandakan bahwa kondisi ekosistem mangrove di Desa Tireman, Rembang masih cukup baik bagi habitat gastropoda. Indeks keseragaman merupakan salah satu indikator yang digunakan untuk menduga kondisi biotik suatu lingkungan penelitian. Nilai indeks keseragaman di lokasi penelitian masuk kedalam kategori rendah. Nilai indeks keseragaman TR I (0.25), TR II (0.15) dan TR III (0.27). Indeks keseragaman memiliki nilai rendah diduga spesies yang sedikit, semakin kecil nilai keseragaman jenis maka semakin kecil pula nilai keseragaman komunitas perairan tersebut. Artinya penyebaran jenis dan jumlah individu tidak sama dan ada kecenderungan suatu komunitas didominasi oleh jenis tertentu. Secara keseluruhan nilai keseragaman yang didapatkan dari hasil penelitian menunjukkan nilai yang bervariasi. Hal ini karena faktor parameter lingkungan yang bervariasi sehingga mempengaruhi adaptasi gastropoda terhadap faktor lingkungan yang ada. Suhu merupakan salah satu faktor yang mempengaruhi distribusi suatu organisme (Merly dan Elviana 2017). Dari hasil pengukuran suhu di ekosistem mangrove Desa Tireman suhu perairan menunjukkan nilai kisaran $24-28^{\circ} \mathrm{C}$. Nilai rata-rata Indeks Dominansi pada TR I $(0,45)$ dan TR III $(0,33)$ tidak ada spesies yang mendominansi. Tidak adanya 
spesies yang mendominansi pada TR I dan TR III diduga karena jumlah spesies dan individu yangditemukan relatif merata. Hal ini dapat terjadi karena setiap stasiun di lokasi mempunyai karakteristik habitat dan kondisi lingkungan seperti suhu, $\mathrm{pH}$, salinitas dan jenis substrat yang tidak jauh berbeda artinya penyebaran spesies dan jumlah individu tidak sama dan ada kecenderungan suatu komunitas didominansi spesies tertentu, begitu pula sebaliknya. Menurut Syamsurial (2011), nilai indeks dominansi yang tinggi menyatakan konsentrasi dominan yang tinggi (ada individu yang mendominansi), sebaliknya jika indeks dominansi rendah maka menyatakan konsentrasi rendah (tidak ada yang mendominansi).

Pola sebaran jenis yang didapatkan termasuk ke dalam kategori mengelompok (clumped) dan acak (random). Pola sebaran jenis gastropoda yang cenderung mengelompok pada lokasi penelitian diduga karena faktor dari sifat gastropoda yang cenderung hidupnya bergerombol menempel pada satu tempat dan interaksi antar spesies menjadi lebih intensif dan menguntungkan dalam hal reproduksi maupun bertahan hidup. Pola sebaran mengelompok disebabkan oleh beberapa hal diantaranya seperti kondisi lingkungan, kebiasaan makan dan cara bereproduksi. Menurut Krebs (1989) pola sebaran dapat dipengaruhi oleh sebaran pakan dalam waktu dan ruang serta kompetisi di dalam pemanfaatan sumberdaya habitat dan juga disebabkan oleh perubahan kondisi lingkungan. Pola sebaran acak pada spesies ini diduga jenis ini ditemukan tidak tersebar merata pada lokasi penelitian. Jenis Cerithidea alata yang sangat jarang ditemui dan hanya ditemui di stasiun TR II ini menunjukkan pola sebaran acak. Jenis ini hidup pada batang dan daun mangrove serta menempel pada batuan besar. Hal ini karena penyebarannya yang tidak sampai ke bagian belakang ekosistem dikarenakan bagian tersebut lebih kering dibandingkan bagian ekosistem mangrove yang lain, walaupun masih tetap ada genangan air yang disebabkan oleh pasang yang merata. Tidak meratanya jenis gastropoda yang tersebar dalam setiap stasiun menunjukkan bahwa adanya habitat tertentu yang disenangi oleh biota tersebut kemungkinan lainnya adalah ekosistem yang terdapat merupakan ekosistem buatan yang selalu terjadi campur tangan manusia yang menyebabkan sedikitnya gastropoda yang ditemui dalam ekosistem mangrove. Menurut Hutama et al. (2019) Tidak meratanya jenis gastropoda yang tersebar dalam setiap stasiun menunjukkan bahwa adanya habitat tertentu yang disenangi oleh biota tersebut atau adanya fauna asli dan pendatang. Berdasarkan kriteria dari Odum (1993), indeks kesamaan komunitas pada semua lokasi penelitian terbagi menjadi 3 kategori yaitu sangat tinggi $(>91 \%)$, tinggi (61-90\%), dan sedang (31-60\%). Kategori sangat tinggi terdapat pada TR II terhadap TR III (93.33\%). Kategori tinggi terdapat pada TR I terhadap TR III (82.35\%) dan TR I terhadap TR II (80\%). Hasil indeks kesamaan komunitas bervariasi antar stasiun penelitian diduga terdapat

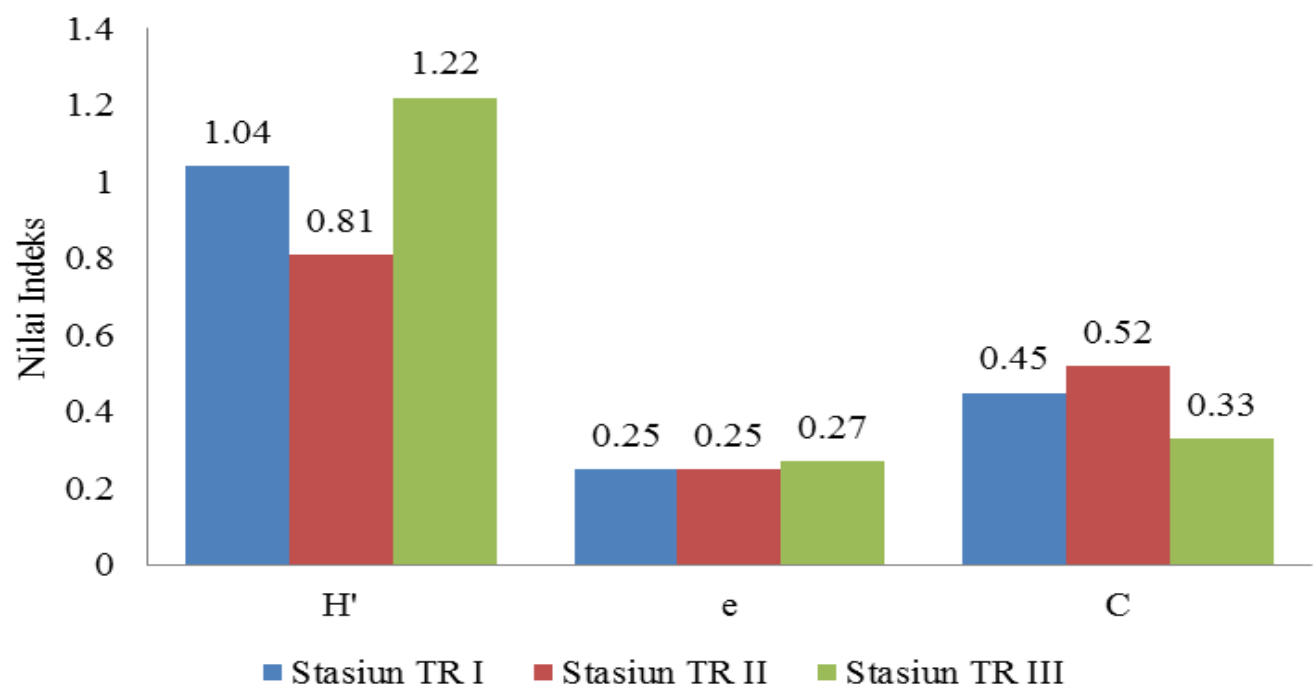

Gambar 3. Perbandingan Nilai Indeks Keanekaragaman $\left(H^{\prime}\right)$, Indeks Keseragaman (e) dan Indeks Dominansi Spesies (C) Antar Stasiun di Area Mangrove Desa Tireman, Rembang, Jawa Tengah 
perbedaan kerapatan vegetasi mangrove pada setiap stasiun penelitian dan perbedaan jarak antar stasiun penelitian. Semakin banyak jenis yang sama di kedua lokasi maka akan semakin besar juga nilai indeks kesamaan komunitas antar kedua lokasi tersebut (Krebs, 1989). Semakin tinggi nilai kesamaan komunitas maka semakin tinggi spesies yang sama ditemukann dan sebaliknya. Frekuensi Kehadiran gastropoda pada tiap stasiun yang menunjukkan nilai frekuensi kehadiran yang bervariasi untuk tiap spesies stasiun dengan rata-rata tiap stasiun berkisar $33,33 \%$ hingga $100 \%$. Cassidula nucleusdan Cassidula aurisfelis merupakan spesies yang memiliki nilai frekuensi kehadiran $100 \%$ artinya spesies tersebut selalu ditemukan pada setiap pengambilan sampel, hal ini diduga karakteristik habitat di ketiga stasiun mendukung untuk kehidupan jenis tersebut, yaitu adanya genangan air yang luas dan daerah yang terbuka

\section{KESIMPULAN}

Penelitian dapat disimpulkan bahwa gastropoda di ekosistem mangrove Desa Tireman, Rembang ditemukan 3 famili dengan 9 spesies. Spesies yang paling sering ditemukan adalah Cassidula aurisfelis dan Cassidula nucleus. Nilai rata-rata Kelimpahan tertinggi di TR I dengan mangrove kategori rapat. Nilai rata-rata Indeks Keanekaragaman $\left(\mathrm{H}^{\prime}\right)$ termasuk dalam kategori rendah - sedang $(0,81-1,22)$. Nilai rata-rata Indeks Keseragaman (e) termasuk dalam kategori rendah $(0,15-0,27)$. Nilai rata-rata Indeks Dominansi $(C)$ menunjukkan tidak adanya dominansi dari spesies tertentu. Pola sebaran gastropoda di lokasi penelitian menunjukkan pola sebaran mengelompok dan acak. Nilai Indeks Kesamaan Komunitas gastropoda dalam kategori tinggi. Frekuensi kehadiran gastropoda termasuk ke dalam kategori jarang hingga sangat sering.

\section{UCAPAN TERIMA KASIH}

Artikel ini merupakan bagian dari skripsi yang berjudul "Struktur Komunitas Gastropoda di Ekosistem Mangrove Desa Tireman, Kec. Rembang, Kab. Rembang, Jawa Tengah", untuk memperoleh gelar Sarjana Strata Satu Program Studi IImu Kelautan, Fakultas Perikanan dan IImu Kelautan Universitas Diponegoro.

\section{DAFTAR PUSTAKA}

Anggraini, D.D. 2016. Analisis Jasa Ekosistem Mangrove dalam Mengurangi Erosi Pantai di Sebagian Pesisir Kecamatan Rembang Kabupaten Rembang. Jurnal Bumi Indonesia.6(3):6169

Annas, N., Suryono \& Rudhi P. 2013. Kajian Konservasi Ekosistem Mangrove Di Desa Pasar Banggi, Kabupaten Rembang. Journal of Marine Research. 9(2):55-64

Fadli, N., Setiawan, I. \& Fadhilah, N., 2012. Keragaman makrozoobenthos di perairan kuala gigieng Kabupaten Aceh Besar. Depik: Jurnal IImu-IImu Perairan, Pesisir dan Perikanan, 1(1):45-52

Food and Agricultural Organization. 2007. The World's Mangroves 1980-2005, A Thematic Study Prepared in the Framework of the Global Forest Resources Assessment 2005. Rome: FAO Forestry Paper. Pp. 23-26.

Hogart, P.J. 2007. The Biology of Mangroves and Seagrasses. Second Edition. Oxford University Press. New York. Page 73-133.

Hutama, H.F.R., Hartati, R. \& Djunaedi, A.. 2019. Makrozoobenthos Gastropoda pada Vegetasi Mangrove di Pesisir Utara Semarang. Buletin Oseanografi Marina. 8(1):37-43

Imam, S., Santoso, A. \& Pribadi, R., 2014. Struktur Komunitas Gastropoda Di Tracking Mangrove Kemujan, Taman Nasional Karimunjawa. Journal of Marine Research, 3(4):595-604.

Krebs, C. J. 1989. Ecological Methodology: The Experimental Analysis of Distribution and Abundance. Harper and Row Publisher, New York. 799 pp.

Merly, S.L. \& Elviana, S., 2017. Korelasi Sebaran Gastropoda dan Bahan Organik Dasar pada Ekosistem Mangrove di Perairan Pantai Payum, Merauke. Dinamika Maritim. Vol. 6, No.1:18-2

Mujiono. 2011. Keanekaragaman Jenis Gastropoda (Mollusca) yang Berasosiasi dengan Ekosistem Mangrove di Taman Nasional Ujung Kulon. Biota: Jurnal IImiah IImu-IImu Hayati, 
15(2):219-226.

Nurfitriani, N., Caronge, W. \& Kaseng, E.S. 2017. Keanekaragaman Gastropoda Di Kawasan Hutan Mangrove Alami Di Daerah Pantai Kuri Desa Nisombalia Kecamatan Marusu Kabupaten Maros. Jurnal Bionature. 18(1):71-79

Nurrudin, N., Hamidah, A. \& Kartika, W.D. 2015. Keanekaragaman Jenis Gastropoda di Sekitar Tempat Pelelangan Ikan (TPI) Parit 7 Desa Tungkal I Tanjung Jabung Barat. Biospecies. 8(2):51-60.

Nyabakken, J.W. 1992. Biologi Laut; Suatu Pendekatan Ekologis. PT. Gramedia. Jakarta

Odum, E.P. 1993. Dasar-Dasar Ekologi Penerjemahan: Samingan, T dan B. Srigandono. Gajahmada University Press. Yogyakarta. 697p.

Printrakoon, C. \& Tëmkin, I., 2008. Comparative ecology of two parapatric populations of Isognomon (Bivalvia: Isognomonidae) of Kungkrabaen Bay, Thailand. The Raffles Bulletin of Zoology, 18:75-94.

Tambayong, F.A., Rudiyanti, S. \& Suryanti, S. 2017. Hubungan Kandungan Bahan Organik dengan Distribusi dan Keanekaragaman Gastropoda padaEkosistem Mangrove Di Desa Pasar Banggi Kabupaten Rembang. Prosiding Seminar Nasional Hasil-hasil Penelitian Perikanan dan Kelautan ke-VI.Hal 601-610 